Conference or Workshop Item (Paper)

Balzter, Heiko; Weedon, Graham; Grey, Will; Los, Sietse; Gerard, France; Combal, Bruno; Bartholome, Etienne; Bartelev, Sergey. 2008 Climate, vegetation phenology and forest fires in Siberia. In: 2008 IEEE International Geoscience \& Remote Sensing Symposium, Boston, 6-11 July 2008. Institute for Electrical and Electronics Engineers.

This version available at http://nora.nerc.ac.uk/5510/

NERC has developed NORA to enable users to access research outputs wholly or partially funded by NERC. Copyright and other rights for material on this site are retained by the authors and/or other rights owners. Users should read the terms and conditions of use of this material at http://nora.nerc.ac.uk/policies.html\#access 


\title{
Climate, vegetation phenology and forest fires in Siberia
}

\author{
Heiko Balzter \\ University of Leicester, Department of Geography \\ Leicester, LE1 7RH, UK \\ hb91@le.ac.uk \\ France Gerard \\ Centre for Ecology and Hydrology (CEH) \\ Monks Wood, Cambridgeshire, PE28 2LS, UK \\ ffg@ceh.ac.uk
}

\author{
Graham Weedon, Will Grey, Sietse Los \\ Climate and Land Surface Systems Interaction Centre, \\ University of Swansea, Department of Geography \\ Singleton Park, Swansea, SA2 8PP, Wales, UK \\ Bruno Combal, Etienne Bartholomé \\ Joint Research Centre of the European Commission \\ I - 21020 Ispra (VA), Italy \\ etienne.bartholome@jrc.it \\ Sergey Bartalev \\ Space Research Institute, Russian Academy of Sciences \\ 117997, 84/32 Moscow, Russia \\ bartalev@smis.iki.rssi.ru
}

\begin{abstract}
A time series of 18 years of fAPAR (fraction of photosynthetically active radiation absorbed by the green parts of vegetation) data from the NOAA AVHRR instrument series was analyzed for interannual variations in the start, peak, end and length of the season of vegetation photosynthetic activity in Central and East Siberia. Variations in these indicators of seasonality can give important information on interactions between the biosphere and atmosphere. A second order local moving window regression model called the "camel back method" was developed to determine the dates of phenological events at subcontinental scale. The algorithm was validated by comparing the estimated dates to phenological field observations. Using spatial correlations with temperature and precipitation data and climatic oscillation indices, we postulate two geographically distinct mechanisms in the system of climatic controls of the biosphere in Siberia: Central Siberia is controlled by an "Arctic Oscillation/temperature mechanism" while East Siberia is controlled by an "El Niño/precipitation mechanism". While the analysis of data from 1982 to 1991 indicates a slight increase in the length of the growing season for some land cover types due to an earlier beginning of the growing season, the overall trend from 1982 to 1999 is towards a slightly shorter season for some land cover types caused by an earlier end of season. The Arctic Oscillation tended towards a more positive phase in the Eighties leading to enhanced high pressure system prevalence but towards a less positive phase in the Nineties. We suggest that the two mechanisms also control the fire regimes in Central and East Siberia. Several extreme fire years in Central Siberia were associated with a highly positive Arctic Oscillation phase, while several years with high fire damage in East Siberia occurred in El Niño years. An analysis of remote sensing data of forest fire partially supports this hypothesis.
\end{abstract}

Keywords: Phenology, fire, climate change, Siberia, forest, growing season.

\section{INTRODUCTION}

The boreal forests of Siberia are particularly vulnerable to climate change because (i) their ecological processes are largely temperature controlled and (ii) climate data show a disproportionately large warming trend in high latitudes. Likely consequences of the warming trend include shifts in the seasonality of the growing season (vegetation phenology) and a potential increase in forest fire frequency. This study aims to undertake an identification of potential coupling mechanisms between large-scale climate patterns (Arctic Oscillation, El Niño), vegetation phenology and fire over Central and Eastern Siberia using a combined analysis of satellite and climate data.

\section{BACKGROUND}

Annual temperature anomalies $(\Delta t)$ from the CRUTEM2 dataset between 1851 and 2004 for Central Siberia $\left(50-70^{\circ} \mathrm{N}\right.$ and $\left.80-120^{\circ} \mathrm{E}\right)$ show a clear warming trend $(\Delta t=0.012$ year 23.476). This observation is matched by warmer spring temperatures in the lower troposphere from Eastern Siberia to Northern Canada in the 1990s (Overland et al. 2002). The observed shift in wind fields from anomalous north-easterly flow in the 1980s to anomalous south-westerly flow in the 1990s during March and April in that region coincided with a systematic shift in the Arctic Oscillation (AO) near the end of the 1980s (Overland et al. 2002). Frey and Smith (2003) also show that West Siberia is warming (most notably in the spring), precipitation is increasing, particularly in winter and particularly autumn and winter temperatures are associated with the AO. Research has shown that over the period 19801995, year-to-year differences in the carbon flux from terrestrial metabolism have almost been as large as variations in the growth rate of atmospheric $\mathrm{CO}_{2}$ (Houghton 2000). 
Depending on the dominant processes, biosphere feedbacks to the climate system can accelerate or slow down climate change (Cox et al. 2000). Fluxes of heat, water, carbon and other greenhouse gases between the land surface and the atmosphere interact in complex non-linear ways (Delworth et al. 1993, Koster et al. 2000).

Climate oscillations have an impact on regional variability and consequently vegetation activity. Los et al (2001) and Buermann et al. (2003) found that two predominant hemispheric-scale modes of covariability are related to teleconnections associated with the El Niño-Southern Oscillation (ENSO) and the AO: While the warm event ENSO signal is associated with warmer and greener conditions in Far East Asia, the positive phase AO leads to enhanced warm and green conditions over large regions in Asian Russia. However, Los et al (2001) found a negative relationship between temperature and vegetation greenness at the time-scales of variability of the North Atlantic Oscillation (NAO), a regional index related to the AO, and ENSO for the Russian part of Asia during the 1980s.

In recent years Siberia has experienced extreme fire years (Sukhinin et al. 2004), which coincided with the AO in its positive phase (Balzter et al. 2005). Fires release carbon and aerosols into the atmosphere and can alter the carbon balance (Kasischke et al. 2005).

We analyzed fAPAR data (fraction of absorbed photosynthetically active radiation) from 1982 to 1999 derived from NOAA-AVHRR over Siberia. Indicators of the start, peak, end and length of the growing season were extracted with a local moving window regression approach. The indicators were then statistically compared to regional scale temperature and precipitation data as well as large-scale climatic modes of variability such as ENSO and AO.

\section{DATA AND METHODS}

\section{A. Satellite data}

The AVHRR FASIR data were derived from Pathfinder red and near infrared AVHRR Land data (PAL) that are corrected for residual effects of sensor degradation and inaccuracies in vicarious calibration, volcanic aerosols, bi-directional reflectance distribution factor (BRDF) effects, cloud effects in tropical forests, short-term aerosol and cloud effects $(<=2$ months and missing data during winter in boreal forests). The fAPAR data for Central and Eastern Siberia were on a $0.08^{\circ}$ grid scale with a temporal resolution of $\sim 10$ days (http://islscp2.sesda.com/ISLSCP2_1/data/vegetation/fasir_bio phys_monthly_xdeg/).

\section{B. The camel back phenology algorithm}

We developed an algorithm to extract indicators of the timing of the start, peak and end of the growing season over boreal Eurasia from phenological remote sensing time series data. Start, peak, end and length of the growing season were automatically estimated for each year. The algorithm is based on local second-order derivatives. The method is described in Balzter et al. (in press) and was motivated by Moulin et al. (1997). First, a window of width 5 dekads is moved over the
fAPAR time series for each pixel separately. Within the temporal window a linear regression of fAPAR against time is calculated. The slope of this local regression is stored. In a second iteration, the second order derivative is calculated using the same moving window linear regression: (i) The start of the growing season is defined as the time point when the second derivative of the moving window regression (5 dekads wide) reaches a local maximum within a 13 dekad window, and the first order slope is positive (fAPAR is increasing), (ii) The peak of the growing season is defined as the time point when fAPAR reaches a local maximum within a 13 dekad window. If consecutive fAPAR values have the same value, the peak is defined as the time when this constant value is first reached, (iii) The end of the growing season is defined as the time point when the second derivative of the moving window regression (5 time points wide) reaches a local maximum within a 13 dekad window, and the first order slope is negative (fAPAR is decreasing), (iv) The length of the green season is defined as the difference between end and start of the season. Multiple peaks did not occur in the boreal ecosystems studied here.

\section{Climate data}

We analysed land air temperature anomalies from the CRUTEM2 dataset on a $5^{\circ}$ grid from http://www.cru.uea.ac.uk/ftpdata/crutem2.zip. $\quad$ Monthly precipitation was obtained from the VASClimO project (http://www.dwd.de/en/FundE/Klima/KLIS/int/GPCC/Projects VASClimO/VASClimO.htm). The monthly AO Index was obtained from the NOAA/ National Weather Service (http://www.cpc.ncep.noaa.gov/products/precip/CWlink/daily_ ao index/monthly.ao.index.b50.current.ascii.table). The AO index is in its negative phase when relatively high pressure systems prevail over the polar region and low pressure systems dominate at mid-latitudes $\left(45^{\circ} \mathrm{N}\right)$. Regional monthly ENSO indices were obtained for Niño $1+2\left(0-10^{\circ} \mathrm{S}\right.$; $\left.90-80^{\circ} \mathrm{W}\right)$, Niño 3 $\left(5^{\circ} \mathrm{N}-5^{\circ} \mathrm{S} ; 150^{\circ}-90^{\circ} \mathrm{W}\right)$, and Niño $4\left(5^{\circ} \mathrm{N}-5^{\circ} \mathrm{S} ; 160^{\circ} \mathrm{E}-150^{\circ} \mathrm{W}\right)$ regions from the NOAA/ National Weather Service (http://www.cpc.ncep.noaa.gov/data/indices/sstoi.indices).

\section{Phenology field data}

Ground observations of vegetation phenology from Siberia were provided by Dr Fedotova (St. Petersburg) for three locations within the study region: Ilir, Bratski district, 5313’0” N, 10041’0” E; Taseevo (Luchki), 570’11” N, 940'50” E; and Krasnoyarsk, 560’0” N, 930’0” E.

\section{E. Land cover data}

The GLC2000 land cover map (Bartalev et al. 2003) was used to stratify the area by land cover type for parts of the statistical analysis. The GLC2000 data were filtered with a 9x9 mode filter and then resampled to the same resolution as the fAPAR data, effectively assigning the most frequent land cover class within each resampling window to the central pixel.

\section{F. Burned area data}

Remotely sensed burned forest area statistics of a large region of Central Siberia from 1992 to 2003 (Balzter et al. 2005) were used. Other satellite derived burned area data were published by Sukhinin et al. (2004) and Bartalev et al. (2007). 


\section{RESUlts}

\section{A. Validation of remote sensing indicators with phenology field data}

The camel back algorithm was validated in a pilot study for the time period from 1995 to 1999 using the phenology field data. The remotely sensed start of season is timed between the snow melt in the forest and the start of the movement of liquid in Betula pubescens (Ehrh.) and B. pendula (Roth). Although the indicator is likely to be influenced by snowmelt as well as the onset of photosynthetic activity, it is valid for looking at anomalies. The remotely sensed peak of season on average occurs shortly after the flowering of Padus racemosa (Lam.), Malus palladiana (Juz.) and Sorbus sibirica (Hedl.), but long before the onset of leaf shedding of Populus tremula (L.), Betula sp. and Larix sibirica (Ldb.). The remotely sensed end of season detects a stage between the first snowfall, close to Larix sibirica (Ldb.) shedding its needles, and shortly before the formation of a permanent snow cover.

\section{B. Land cover analysis of phenological trends}

From 1982 to 1999 all but three land cover classes showed an advance of the start of season indicator (negative slope over time), with Urban areas (0.74 d/a [days per year]), Deciduous Broadleaf Forest (0.46 d/a), Forest - Cropland complexes (0.62 $\mathrm{d} / \mathrm{a})$, Humid grasslands (0.35 d/a) and Cropland - Grassland complexes $(0.45 \mathrm{~d} / \mathrm{a})$ being statistically significant $(\mathrm{p}<0.1)$. All land cover types except Barren tundra, Palsa bogs, Broadleaf deciduous shrubs and Saltmarsh show a significant trend towards an earlier peak of the growing season (advance between 0.29 and $0.76 \mathrm{~d} / \mathrm{a} ; \mathrm{p}<0.1$ ). A trend towards an earlier end of the season is detected for all classes except Riparian vegetation, Steppe and Broadleaf deciduous shrubs (advance between 0.27 and $0.57 \mathrm{~d} / \mathrm{a} ; \mathrm{p}<0.1$ ). Palsa bogs, Forest Natural Vegetation complexes, Prostrate shrub tundra and Sedge tundra were identified as showing a significant decrease in the length of season (shortening between 0.25 and $0.47 \mathrm{~d} / \mathrm{a}$; $\mathrm{p}<0.1$ ). We repeated the analysis only for the years 1982 to 1991 . The results are that between 1982 and 1991 all but two land cover classes show a trend towards an earlier start of season, although only Forest - Cropland complexes (1.39 d/a) and Urban areas (0.89 $\mathrm{d} / \mathrm{a})$ are statistically significant $(\mathrm{p}<0.1)$. All of the classes show a trend towards an earlier peak of season, with about half of the classes indicating a statistically significant trend (Sedge tundra, Prostrate shrub tundra, Barren tundra, Bogs and marshes, Croplands, Cropland - Grassland complexes, Palsa bogs, Shrub tundra, Needle-leaf evergreen shrubs, Urban, Riparian vegetation; advance between 0.71 and $1.18 \mathrm{~d} / \mathrm{a} ; \mathrm{p}<0.1)$. Steppe and Croplands tended towards an earlier end of season $(p<0.1)$. The length of season between 1982 and 1991 showed a slight trend towards longer seasons (positive slopes) for most classes, but none of them statistically significant $(\mathrm{p}>0.1)$. These findings for the shorter period from
1982 to 1991 would lead to different conclusions from the analysis of the full time series from 1982 to 1999, which indicates a slight shortening of the season.

\section{Correlation of climate with phenology anomalies}

ENSO and AO indicators were compared to phenological anomalies. The length of season anomalies show significantly negative correlations between the El Niño indicators and length of season anomalies in Eastern Siberia (e.g. NINO3 east of $130^{\circ}$ in Fig.1). In years with a positive El Niño index East Siberia had a shorter than average growing season. When the $\mathrm{AO}$ is in its positive phase the growing season tended to start earlier, reach its peak earlier but also end earlier in most regions (Fig.1). It also became evident that the $\mathrm{AO}$ is correlated with heat waves in the more continental parts of Central Siberia between $80^{\circ}$ and $140^{\circ} \mathrm{E}$, but ENSO does not show a strong correlation with temperature anomalies in the region at an annual time scale. Generally, the AO is not, however, correlated significantly with precipitation anomalies of the same year. ENSO showed a correlation with droughts in the north and in the oceanic climate regions east of $135^{\circ} \mathrm{E}$. Thus a stratification of the region into continental climate (west of $140^{\circ} \mathrm{E}$ ) and oceanic climate (east of $140^{\circ} \mathrm{E}$ ) seems appropriate for the understanding of climate/vegetation interactions in Siberia. The continental part of Central Siberia is influenced more by the Arctic Oscillation, which is associated with temperature anomalies, while the oceanic part of East Siberia is influenced more by El Niño events in the Pacific, which coincide with dry years.
Figure 1. Correlations between the NINO3 and Arctic Oscillation index with vegetation phenological anomalies. (top) NINO3 Index and length of season anomalies (bottom) Arctic Oscillation Index and start of season anomalies. Grey boxes $=$ missing values or coefficient not significant (two-sided $\mathrm{p}>0.1$ ). Black $=$ coastlines, white $=$ national boundaries.

\section{Climatic controls of the fire regime}

The two proposed mechanisms are likely to have an impact on the regional fire regime. Balzter et al. (2005) showed that the $\mathrm{AO}$ and summer temperatures can explain $80 \%$ of the interannual variability of burned forest area in Central Siberia. 
In 2002 a cluster of fires raged in East Siberia (Sukhinin et al., 2004), while the fire season in Central Siberia was relatively calm. 2002 was an El Niño year with an Arctic Oscillation index close to zero. Annual burned forest area statistics derived from SPOT-VEGETATION from 2000-2004 (Bartalev et al., in press) showed that high fire activity over these 5 years in the Siberia macroregion coincided with a positive AO, while the Far Eastern macroregion had higher fire activity in years with a positive El Niño index NINO3 (Fig.2). Using forest fire statistics extracted from the dataset by Sukhinin et al. (2004), it is evident that the most extreme forest fire years in the Central Siberia region (the Siberia-II study region) coincide with the Arctic Oscillation being in its positive phase (Fig.2) but do not show an association with extreme El Niño years. For the Far Eastern region the most extreme fire years also coincided with a positive Arctic Oscillation. The two most extreme fire years happened in years with a positive El Niño index.

The observational evidence from different forest fire data sources, that were derived using different remote sensing data and methods, partially supports the hypothesis that the Central Siberian "Arctic Oscillation/temperature mechanism" and the East Siberian "El Niño/precipitation mechanism” have an impact on regional fire activity.

Since 1950 the Arctic Oscillation shows a statistically

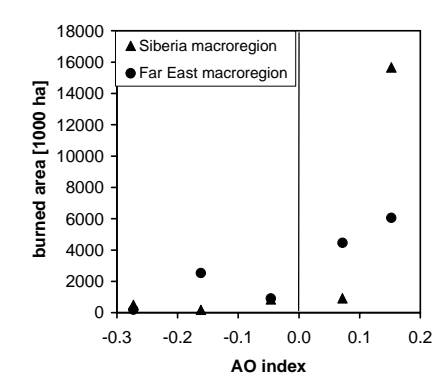

(a)

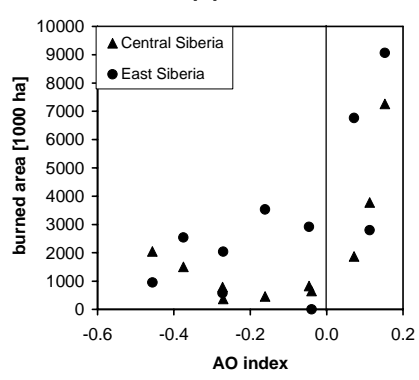

(c)

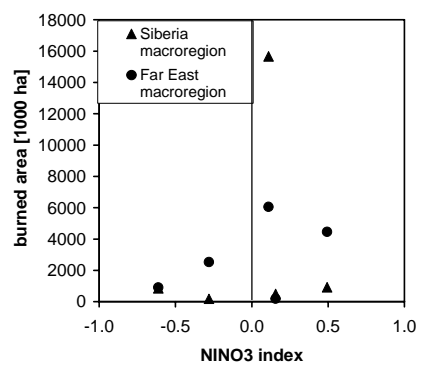

(b)

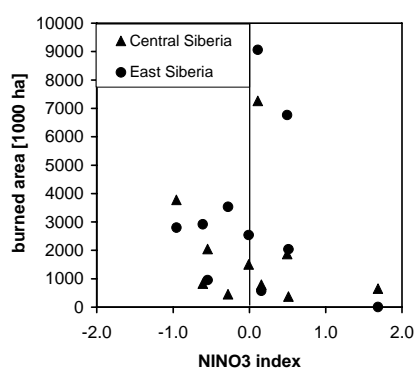

(d)
Figure 2. Burned forest area statistics for more continental and more eastern regions of Siberia from remote sensing in relation to the Arctic Oscillation Index and the NINO3 indicator. (a) data from Bartalev et al. (2004) vs. Arctic

Oscillation Index, (b) data from Bartalev et al. (2004) vs. NINO3 anomalies, (c) data from Sukhinin et al. (2004) vs. Arctic Oscillation Index, (d) data from Sukhinin et al. (2004) vs. NINO3 anomalies.

significant temporal trend towards the positive phase, which is likely to lead to more frequent heat waves in Central Siberia. El Niño indices also show a slight trend towards stronger El Niño years, albeit only the NINO4 sea surface temperature has a statistically significant increasing linear slope. A possible consequence is an increased frequency of droughts in East Siberia with an accelerated fire regime.

\section{ACKNOWLEDGMENT}

This work was supported by GEOLAND (EC Proposal Reference No. FP-6-502871), the Climate and Land Surface Systems Interaction Centre (CLASSIC) and the Natural Environment Research Council (UK).

\section{REFERENCES}

[1] Balzter, H., Gerard, F., Weedon, G., Grey, W., Combal, B., Bartholome, E., Bartalev, S. and Los, S., in press, Coupling of vegetation growing season anomalies with hemispheric and regional scale climate patterns in Central and East Siberia, Journal of Climate

[2] Balzter, H., Gerard, F.F., George, C.T., Rowland, C.S., Jupp, T.E., McCallum, I., Shvidenko, A., Nilsson, S., Sukhinin, A., Onuchin, A. and Schmullius, C., 2005: Impact of the Arctic Oscillation pattern on interannual forest fire variability in Central Siberia, Geophys. Res. Letters, 32, doi:10.1029/2005GL022526

[3] Bartalev S.A., V.A. Egorov, E.A. Loupian and I.A. Uvarov, in press: Multi year circumpolar assessment of the area burnt in boreal ecosystems using SPOT VEGETATION, Int. J. Rem. Sens. (ID TRES LET 2005 0098.R2)

[4] Bartalev, S., Belward, A.S., Erchov, D. and Isaev, A.S., 2003: A new SPOT4 VEGETATION derived land cover map of Northern Eurasia. Int. J. Rem. Sens., 24, 1977-1982.

[5] Buermann, W., B. Anderson, C. J. Tucker, R. E. Dickinson, W. Lucht, C. S. Potter, and R. B. Myneni, 2003: Interannual covariability in Northern Hemisphere air temperatures and greenness associated with El Niño-Southern Oscillation and the Arctic Oscillation, J. Geophys. Res., 108(D13), 4396, doi:10.1029/2002JD002630, 2003.

[6] Cox, P.M., R.A. Betts, C.D. Jones, S.A. Spall, and I.J. Totterdell, 2000: Acceleration of global warming due to carbon-cycle feedbacks in a coupled climate model. Nature, 408, 184-187.

[7] Delworth, T. and S. Manabe, 1993: Climate variability and landsurface processes. Adv. Water Resources, 16, 3-20.

[8] Frey, K. E., and Smith, L. C., 2003: Recent temperature and precipitation increases in West Siberia and their association with the Arctic Oscillation. Polar Research, 22, 287-300.

[9] Houghton RA. 2000: Interannual variability in the global carbon cycle. J. Geophys. Res., 105, 20121-20130.

[10] Kasischke, E. S., E. J. Hyer, P. C. Novelli, L. P. Bruhwiler, N. H. F. French, A. I. Sukhinin, J. H. Hewson, and B. J. Stocks, 2005: Influences of boreal fire emissions on Northern Hemisphere atmospheric carbon and carbon monoxide, Global Biogeochem. Cycles, 19, GB1012, doi:10.1029/2004GB002300.

[11] Koster, R.D., M.J. Suarez, and M. Heiser, 2000: Variance and predictability of precipitation at seasonal-to-interannual timescales. J. Hydrometeorol., 1, 26-46.

[12] Los S. O., G.J. Collatz, L. Bounoua, P. J. Sellers and C. J. Tucker, 2001: Global interannual variations in sea surface temperature, land surface temperature and land surface vegetation air temperature and precipitation, J. Climate, 14, 1535-1549.

[13] Moulin, S., Kergoat, L., Viovy, N. and Dedieu, G., 1997: Globalscale assessment of vegetation phenology using NOAA/AVHRR satellite measurements. J. Climate, 10, 1154-1170.

[14] Overland, J. E., Wang, M. Y., and Bond, N. A., 2002: Recent temperature changes in the Western Arctic during spring. J. Climate, 15, 1702-1716.

[15] Sukhinin, A. I., French, N. H. F., Kasischke, E. S., Hewson, J. H., Soja, A. J., Csiszar, I. A., Hyer, E. J., Loboda, T., Conrad, S. G., Romasko, V. I., Pavlichenko, E. A., Miskiv, S. I., and Slinkina, O. A., 2004: AVHRR-based mapping of fires in Russia: New products for fire management and carbon cycle studies, Rem. Sens. Environ., 93, 546564. 